\title{
The relationship between perceived training and development and employee retention: the mediating role of work attitudes
}

\begin{abstract}
This paper considers how utilizing a model of job-related affect can be used to explain the processes through which perceived training and development influence employee retention. We applied Russell's model of core affect to categorize four different forms of work attitude, and positioned these as mediators of the relationship between perceived training and development and intention to stay. Using data from 1,191 employees across seven organizations, multilevel analyses found that job satisfaction, employee engagement, and change-related anxiety were significantly associated with intention to stay, and fully mediated the relationship between perceived training and development and intention to stay. Contrary to our hypotheses, emotional exhaustion was not significantly associated with intention to stay nor acted as a mediator when the other attitudes were included. These findings show the usefulness of Russell's model of core affect in explaining the link between training and development and employee retention. Moreover, the findings collectively suggest that studies examining employee retention should include a wider range of work attitudes that highlight pleasant forms of affect.
\end{abstract}

Keywords: employee retention, perceived training and development, job-related affect, multilevel analysis, work attitudes

NOTE: This is the accepted pre-publication version of Fletcher, L., Alfes, K., and Robinson, D. (in press). The relationship between perceived training and development and employee retention: the mediating role of work attitudes. The International Journal of Human Resource Management.

\section{Introduction}

Training and development (T\&D) is a systematic approach to developing and enhancing employee skills, abilities and knowledge for the purpose of increasing organizational effectiveness (Aguinus \& Kraiger, 2009). As an overarching human resource management (HRM) practice it is often considered, and evidenced, to be a broad collection of activities that refer to continual learning 
and development of general job- and career-related skills (e.g. Boon, den Hartog, Boselie, \& Paauwe, 2011). Previous research demonstrates that perceived T\&D is associated with higher levels of retention (Aguinus \& Kraiger, 2009), as T\&D strengthens the social exchange relationship between the employee and their employer (Dysvik \& Kuvaas, 2008).

More recently, researchers have become interested in understanding the exact mechanisms that underlie this relationship (e.g. Koster, de Grip, \& Fourage, 2011). For example, Koster et al. (2011) demonstrated that job satisfaction partially mediated the relationship between perceived support in employee development and intention to quit. In contrast, Dysvik and Kuvaas (2008) showed that intrinsic motivation partially mediated the relationship between perceived T\&D and turnover intentions, and Newman, Thanacoody, and Hui (2011) found that perceived availability of training was related indirectly to turnover intentions via affective and continuance commitment.

While these studies have enhanced our understanding of how T\&D is related to retention, they identify a broad range of attitudes, where each, individually, only partially mediates this relationship. This indicates that the mediation space has not been fully explored theoretically or empirically. Hence, to date, there is no conclusive evidence as to why $T \& D$ relates to intentions to stay. Exploring mediators individually is problematic for a range of reasons. Firstly, it encourages researchers to add potential mediators into the literature with little consideration of how they are differentiated from others. Therefore, there may be a number that overlap conceptually, which makes it difficult to clarify the exact processes through which perceived T\&D influences employee retention. Secondly, examining mediators in isolation limits the degree to which we can be sure that the mediator is practically important. Some may overpower others, or have specific effects, and so it is crucial to include a comprehensive range of potential mediators 
within analyses in order to untangle the mechanism through which perceived T\&D influences retention. Thirdly, work attitudes and levels of retention may vary significantly across different settings, particularly between public and private sectors (Abualrub, Omari, \& Al-Zaru, 2009; Trinchero, Borgonovi, \& Farr-Wharton, 2014). Therefore, there is a need to examine the links between perceived T\&D, work attitudes, and employee retention across a range of organizations.

The present study attempts to address these issues by drawing from and testing a model of job-related affect that we propose mediates the relationship between perceived T\&D and intention to stay. More specifically, we use the conceptual and neurological underpinnings of Russell's (1980) model to help organize and identify a range of attitudes that each connotes a specific aspect of positive or negative work-related wellbeing that connects $T \& D$ with employee retention, based on their level of arousal and pleasure. We seek to contribute to the literature on T\&D in at least two ways.

First, we introduce Russell's (1980) model of core affect as a suitable framework for identifying a 'full' range of work attitudes that are associated with both T\&D and employee retention. Although a multitude of work attitudes have been identified within the literature, there is no overarching framework that organizes them according to their affective properties. We propose that work attitudes can be categorized into four groups based on the quadrants of Russell's (1980) model. More specifically, we identify that the work attitudes of job satisfaction, emotional exhaustion, employee engagement and change-related anxiety each occupy a specific quadrant, and are each related to retention.

Second, we apply this framework to better understand the cognitive-affective pathways through which perceived T\&D impacts on intentions to stay. As individuals appraise events cognitively as well as emotionally (Colquitt et al., 2013), an integrated perspective that considers both cognition and affect is needed in order to fully understand 
why organizational factors, such as T\&D relate to important employee outcomes, such as retention. The present paper draws on Russell's (1980) affect-based model to suggest that employees will cognitively evaluate the degree to which they have received opportunities for $T \& D$, and will emotionally respond to having received $T \& D$ within their organization. Clarifying these pathways will help practitioners facilitate employee retention, and will strengthen the business case for investing in training and development, particularly during periods of economic instability and organizational change. We also test our model across different organizations and sectors, thus increasing the generalizability of the findings.

In sum, this study builds and tests a mediation model that links perceived T\&D to intention to stay (as represented by Figure 1). In doing so, we aim to bring clarity to HRM research by clearing up the mediation space that links perceptions of HRM practices with employee outcomes. We test our hypotheses on a multilevel dataset representing 1,191 employees from seven organizations in the United Kingdom.

\section{INSERT FIGURE 1 HERE}

\section{The importance of perceived training and development}

$\mathrm{T} \& \mathrm{D}$ gives the employee opportunities to acquire and develop valuable resources in the form of skills, abilities and knowledge (Koster et al., 2011). Thus, it represents a crucial way to increase employee retention as it elicits strong obligations, within the employee, to repay the organization for investing in their personal and career development (Lee \& Bruvold, 2003). However, there is a need to differentiate between levels of analysis when examining the impact of HRM practices on employee outcomes, such as employee retention (Wright \& Boswell, 2002; Wright \& Nishii, 2007). Intended practices, as developed by the HRM department, capture an organization's strategic HRM intentions. They are typically interpreted by various line managers, who implement 
these HRM practices in their day to day work with employees. Employees perceive and react to these HRM practices in different ways depending on a range of factors such as past experiences and attributions that they each make about the reasons why management have enacted them (Nishii, Lepak, \& Schneider, 2008). The present study focuses on perceived T\&D as it is these individual-level perceptions of an HRM practice that have the most significant and influential effect on employee attitudes and behaviours (Guest, 2002).

\section{Russell's model of core affect and its application to work attitudes}

The differentiation between work attitudes has been debated for many years, with evidence, on one hand, indicating that some attitudes may be better conceptualized as a unified general factor (e.g. Harrison, Newman, \& Roth, 2006) and evidence, on the other, suggesting that although many work attitudes are related to one another, they are separate and distinct constructs with different foci and effects (e.g. Tett \& Meyer, 1993). Although this debate is still ongoing, the majority of research on work attitudes treats them as independent and distinct constructs. Therefore, being able to organize work attitudes in a systematic way is important because it not only ensures differentiation and distinction between them, but also integrates them into a unified framework. In other words, it enables greater precision of prediction and enhances our understanding of the different properties and mechanisms of a range of attitudes.

Inherent in definitions of many work attitudes, such as job satisfaction, is the positioning of affect as a fundamental property (Warr, Bindl, Parker, \& Inceoglu, 2014). Affects are "primitive, universal, and simple, irreducible on the mental plane" (Russell, 2003, p.148) and refer to a wide range of emotions, moods and feelings that can be organized along two dimensions: pleasure - signifying pleasant affect at one end and unpleasant affect at the other (i.e. affective valence); and arousal - representing activated 
affect at one end and deactivated affect at the other (i.e. readiness for action/expending energy). Russell (1980) combined these two dimensions to form a model of 'core affect' neurophysiological states that are conscious and non-reflective. The model identifies four main forms of core affect, specified by the quadrants made by the intersecting pleasure (horizontal plane) and arousal (vertical plane) dimensions. The pleasant, activated quadrant refers to feelings such as enthusiasm and excitement; the pleasant, deactivated quadrant signifies feelings of contentment and calmness; the unpleasant, deactivated denotes feelings of dejection and boredom; and the unpleasant, activated indicates feelings of tension and anxiety.

Researchers have increasingly used this model to categorize affect based responses (Bakker \& Oerlemans, 2010; Bakker, Albrecht, \& Leiter, 2011; Schaufeli, 2014; Warr et al., 2014), and argued that although work attitudes are related to one another, they are distinct enough to represent specific forms of attitude that can be differentiated by their affective properties. In the present paper we follow this argumentation and take Russell's (1980) model as a starting point to understand the attitudinal antecedents of intention to stay. We focus on measuring attitudes rather than affect directly because an attitude is an evaluative response to one's environment directed at a known object, in this case one's job, whereas affect is a non-evaluative response that is not derived from a specific stimulus nor is it directed towards a known object (cf. Eagly \& Chaiken, 2007; Russell, 2003). Therefore, attitudes are more likely to directly influence employee outcomes as they have a specific evaluative function that can drive action and behaviour. In fact, HRM scholars have argued that employees react to HRM practices attitudinally, and that these attitudinal reactions drive subsequent behaviour, such as the decision to stay or leave an organization (Guest, 2002; Wright \& Nishii, 2007). In line with Bakker et al. (2011) and Schaufeli (2014) we position emotional 
exhaustion within the unpleasant, deactivated quadrant; job satisfaction within the pleasant, deactivated quadrant; and employee engagement within the pleasant, activated quadrant. Furthermore, we argue that the affective underpinnings of change-related anxiety align with those of the unpleasant, activated quadrant.

Emotional exhaustion is a core facet of burnout and refers to being drained and depleted of emotional energy. It reflects a passive withdrawal from the job that reduces the employee's capabilities of maintaining a sense of emotional involvement in their work (Maslach, Schaufeli, \& Leiter, 2001). Individuals who experience high levels of emotional exhaustion find it difficult to psychologically connect with their environment (Alarcon, 2011). As a result, these individuals lack the motivation and desire to maintain their involvement in their work activities, which results in lower intentions to stay with the current organization (Maslach et al., 2001). A meta-analysis by Alarcon (2011) demonstrates that individuals who experience high levels of emotional exhaustion are less inclined to stay than those who experience low levels of emotional exhaustion, and some studies have shown that although levels of emotional exhaustion vary across different organizations and sectors, emotional exhaustion negatively influences employees' attitudes towards their employment (e.g. Vigoda-Gadot \& Kapun, 2005).

Hypothesis 1: Emotional exhaustion will be negatively associated with intention to stay.

Job satisfaction is defined as a positive evaluation of one's job that results from perceiving that one's actual job outcomes are commensurate with the outcomes one desires (Schleicher, Hansen, \& Fox, 2010). It is a positive state that elicits moderate-tolow arousal because it relates to the individual feeling that their job provides an acceptable level of what is desired (Locke, 1976). Job satisfaction has long been viewed as a causal factor that promotes intentions to stay with the organization because it is a pleasant psychological state; the individual feels content with the work that they do and 
the job role they perform (Locke, 1976). Therefore, satisfied employees are motivated to sustain these positive experiences by continuing to participate in social exchanges between themselves and the organization, which further reinforces their intentions to stay with the organization (Koster et al., 2011). Indeed, meta-analytic evidence has demonstrated that those who are satisfied at work are more likely to want to stay rather than leave (Griffeth, Hom, \& Gaertner, 2000), and studies have shown that employees from different organisations and sectors vary in their levels of job satisfaction, yet the relationship between job satisfaction and intent to stay is shown to be positive (e.g., Abulalrub et al., 2009)

Hypothesis 2: Job satisfaction will be positively associated with intention to stay.

Employee engagement can be defined as "a positive attitude held by the employee toward the organisation and its values. An engaged employee is aware of business context, and works with employees to improve performance" (Robinson, Perryman, \& Hayday, 2004, p.4, see also Jenkins \& Delbridge, 2013). Employee engagement is a positive and activated attitude because it reflects a sense of high arousal, energy and involvement with one's work (Parker \& Griffin, 2011). Engaged employees will feel strongly affiliated to the organization because they perceive their work to be meaningful and fulfilling (Saks, 2006). Therefore, employees who are highly engaged will be more likely to stay with the organization than those who exhibit low levels of engagement because they have a strong personal connection with the organization and their work role. This connection is a powerful signal to the employee that there is a mutually beneficial relationship between themselves and their employer, which should be maintained by staying with the organization (Saks, 2006). A recent evidence synthesis found support for this proposition (Bailey, Madden, Alfes, \& Fletcher, 2015), and while there is some evidence that engagement varies across different organizations and sectors, 
engaged employees across all sectors are more likely to stay with their employer (e.g., Trinchero et al., 2014)

Hypothesis 3: Employee engagement will be positively associated with intention to stay.

Lastly, change-related anxiety is an emotional state that refers to feeling overwhelmed by changes occurring within the work environment, and may reflect similar psychological responses as work intensity (cf. Berneth, Walker, \& Harris, 2011; Burke, Singh, \& Fiksenbaum, 2010). It can be seen as a specific form of job anxiety because the individual feels uncertainty about the nature and impact of impeding changes, as well as a constant drive to work hard in order to adapt to such changes. These experiences cause anxiety and worry and so such feelings reflect "an emotional state of perceived apprehension and increased arousal" (Jensen, Patel, \& Messersmith, 2013, p.1703). Change-related anxiety, rather than job anxiety, was focused on in the present study because the work environments that respondents were working in at the time of the study were highly demanding, unstable contexts due to the UK economic recession. Many of the organizations in the sample, particularly the public and voluntary organizations, had experienced significant reductions in funding or revenue as a result of the recession. They were under pressure to implement significant cost-cutting initiatives, such as restructuring, streamlining services, and redundancies, which had increased feelings of anxiety due to heightened job insecurity and uncertainty of the future. Many changes occurring within the organizations during the time of data collection had impacted, to varying degrees, on employees' feelings of anxiety and stress. For instance, two of the voluntary organizations were significantly changing their HRM practices to develop a different culture, the public sector organizations were either planning or implementing significant structural changes, and the private organization was altering employee terms and conditions as well as day-to-day working practices. When employees experience 
such a negative, yet arousing emotional state, they are unable to replenish the energies needed to sustain healthy functioning and so they must withdraw themselves in order to conserve their resources (Hobfoll, 1989). An initial action that an employee can take to conserve resources is to cognitively withdraw from their organization, i.e. reduced intention to stay. Indeed, studies have found that in organizations undergoing significant change employees who do not cope well with the changes are more likely to leave the organization (Cunningham, 2006), and that although work-related stress and anxiety varies across different organizations and sectors, such perceived stress negatively impacts on employee attitudes towards their employment (e.g., George \& Zakkariya, 2015; Vigoda-Godot \& Kapun, 2005)

Hypothesis 4: Change-related anxiety will be negatively associated with intention to stay.

In sum, we propose that the work attitudes of job satisfaction, emotional exhaustion, employee engagement and change-related anxiety reflect different forms of job-related affect, which are each related to intentions to stay with the organization. Thus, they represent distinct, yet related conceptual spaces (see Figure 2), that help to categorize and explain the mediation pathways of the relationship between T\&D and intent to stay (see Figure 1). In the following sections we derive our hypotheses regarding the mediation pathways.

\section{INSERT FIGURE 2 HERE}

\section{The mediating role of work attitudes in the relationship between perceived training and development and intentions to stay}

The relationship between $T \& D$ and intentions to stay is not direct, but rather it is mediated by the attitudes that employees hold of their work and the working environment 
(Guest, 2002). Indeed, prior studies have provided evidence that a range of individual work attitudes have a mediating role in the relationship between perceived training and development and intentions to stay or leave the organization (e.g. Dysvik \& Kuvaas, 2008; Koster et al., 2011; Newman et al., 2011).

In this paper, we have applied Russell's (1980) model of core affect to organize potential mediating attitudes according to their affective properties. Recently, Bakker and Oerlemans (2011) argue that Russell's (1980) model can be used to distinguish between two main types and effects of work-related subjective wellbeing: positive forms and effects that can be high (e.g. engagement) or low (e.g. job satisfaction) in activation, and negative forms and effects that can also be high (e.g. anxiety) and low (e.g. emotional exhaustion) in activation. Using this distinction, we firstly focus on the negative wellbeing pathway and propose that perceived $T \& D$ acts to promote employee retention by preventing negative forms of wellbeing. This is because training provides employees with psychological skills, such as resilience, which helps them to cope with changes within their environment and, as a result, leaves them less emotionally exhausted and anxious (Baruch \& Lambert, 2007; Robertson, Cooper, Sarkar, \& Curran, 2015). Reducing emotional exhaustion and change-related anxiety, in turn, will increase retention because feeling less exhausted and anxious will make withdrawing from the organization less likely (Warr et al., 2014), and make one's commitment to the organization stronger (Bernerth et al., 2011).

Secondly, we follow the positive wellbeing effects according to Russell's framework and argue that perceived T\&D acts to facilitate employee retention by developing positive forms of wellbeing. This is because perceptions of T\&D signal to the employee that the organization has fulfilled their obligation to provide adequate resources and skills needed to perform activities that can lead to the fulfilment of 
extrinsic needs (Lee \& Bruvold, 2003). As a result, the individual is more satisfied with their job, and in turn is happy to stay with the organization. Moreover, the employee will feel more engaged because perceived opportunities for training facilitates the fulfilment of intrinsic psychological needs, such as meaningfulness, safety and availability, which elicits pleasant, activated feelings, such as enthusiasm, that energize the employee to become more involved in their work (Fletcher, 2016a; 2016b). This will, and as such, strengthen their intention to stay with the organization as they want to continue to invest themselves in their work (Parker \& Griffin, 2011).

Hypothesis 5a: Emotional exhaustion will mediate the relationship between perceived $\mathrm{T} \& \mathrm{D}$ and intention to stay.

Hypothesis 5b: Change-related anxiety will mediate the relationship between perceived $\mathrm{T} \& \mathrm{D}$ and intention to stay.

Hypothesis 5c: Job satisfaction will mediate the relationship between perceived T\&D and intention to stay.

Hypothesis 5d: Employee engagement will mediate the relationship between perceived $\mathrm{T} \& \mathrm{D}$ and intention to stay.

Finally, we propose that the work attitudes of job satisfaction, employee engagement, emotional exhaustion, and change-related anxiety, together, will fully mediate the relationship between perceived $T \& D$ and intention to stay. This is because the affective states associated with Russell's four quadrants have been found to exert differential effects on employee outcomes (Warr et al., 2014). We argue that as each work attitude reflects a specific cognitive-affective response, they will operate together to influence broader employee behaviour. 
Hypothesis 6: The work attitudes of emotional exhaustion, change-related anxiety, job satisfaction, and employee engagement will, together, fully mediate the relationship between perceived $\mathrm{T} \& \mathrm{D}$ and intention to stay.

\section{Method}

\section{Sample Characteristics}

A total of 1,809 employees from seven organizations based in the UK received the IES employee engagement survey between 2008 and 2012. The data was collected via a number of commissioned research projects on the employment relationship that IES undertook within this timeframe. Each organizational sample had data collected at one point in time within the five year timeframe, and approximately one to two samples were collected per year. This research design is in line with other research studies that have focused on gaining a large dataset from multiple organizations (Harter, Schmidt, \& Hayes, 2002; Langford, 2009; MacCormick \& Parker, 2010). We decided to use the full sample rather than focus on the most recent sub-sample in order to gain a large sample size and to achieve maximum power. Responses were received from 1,191 employees, constituting a $65.8 \%$ response rate. $52 \%$ of respondents were female; the median age category was 30-39 years. Responses ranged from 26 to 399 employees for each organization (median $=88$ employees). A summary of the organizations is given in table 1 , where it shows that there was substantial variation between the organizations with regard to workforce composition and the diversity of sectors being represented.

\section{INSERT TABLE 1 HERE}

\section{Measures}

As the present study aims to capture an individual's work-related attitudes and their impact on the individual's intent to stay, self-report measures were used because they are a reliable approach to understand how employees feel about their work situation and their behavioural intentions. All measures that follow, unless otherwise stated, use a 
5-point Likert scale (strongly agree, agree, neither agree/disagree, disagree, strongly disagree) and were taken from the IES employee engagement survey (Robinson, Hooker, \& Hayday, 2007).

The IES employee engagement survey was initially designed in 2004 (Robinson et al., 2004) and was consolidated in 2007 (Robinson et al., 2007). It is an evidencebased employee attitudes questionnaire that is grounded from the literature on the employment relationship. It is used primarily by organizations who want to understand the perceptions and attitudes of their employees so that they can better design their internal HRM strategies and initiatives. Therefore, it provides an opportunity to gain data from a wide range of organizations. The questionnaire is usually administered as a oneoff or annually, and has been used by over 20 organizations since 2004 (although only 7 have agreed for their data to be used for research purposes). To assess the validity of the IES questionnaire, we collected additional data to compare the psychometric properties of the IES scales to alternative published scales ${ }^{1}$. All items for the measures in the present study are included in Appendix 1.

\section{Perceived T\&D}

A three-item perceived T\&D scale was taken from the IES employee engagement survey (Robinson et al., 2007). An example item is 'I am encouraged to develop new skills'. Inter-item reliability was $\alpha=.82$.

\section{Job Satisfaction:}

A three-item job satisfaction scale was taken from the IES employee engagement survey (Robinson et al., 2007). An example item is 'Overall, I am satisfied with my job'.

\footnotetext{
${ }^{1}$ This results from these additional analyses are available from the first author upon request.
} 
Inter-item reliability was $\alpha=.91$.

\section{Emotional Exhaustion:}

A three-item emotional exhaustion scale was taken from the IES employee engagement survey (Robinson et al., 2007). An example item is 'I have felt emotionally drained by my work'. Inter-item reliability was $\alpha=.91$.

\section{Employee Engagement:}

The IES 12-item measure of employee engagement (Robinson et al., 2007) was used. The measure covers the following content: a) pride in the organization (e.g. I speak highly of this organization to my friends'); b) belief that the organization provides good products/services and enables the employee to perform well (e.g. 'I would be happy to recommend this organization's products/services to my friends and family'); c) a willingness to behave altruistically and go beyond what is required (e.g. 'I try to help others in this organization whenever I can'); and d) an understanding of the 'bigger picture' (e.g. 'I find that my values and the organization's are very similar'). Inter-item reliability was $\alpha=.85$.

\section{Change-related Anxiety}

A two-item change-related anxiety scale was taken from the IES employee engagement survey (Robinson et al., 2007). An example item is 'I sometimes feel overwhelmed by the pace of change here'. Inter-item reliability was $\alpha=.88$.

\section{Intention to stay:}

A single item measured the employee's intentions to stay at their current organization: 'Which of the following statements most reflect your current intentions? 1Plan to leave as soon as possible, 2- Likely to leave within the next year, 3- Likely to stay for at least another year, 4- Plan to stay for the foreseeable future'. Single item scales 
measuring turnover intentions (positive or negative valence) have been used in a number of academic studies (e.g. Ng \& Butts, 2009), and, in general, single item scales have been found to have good reliability and face validity (Bergkvist \& Rossiter, 2007).

\section{Control variables:}

Gender $(0=$ male, $1=$ female $)$, age $(1=<30$ years, $2=30-39$ years, $3=40-49$ years, $4=50+$ years $)$, tenure $(1=<1$ year, $2=1-3$ years, $3=4-7$ years, $4=7+$ years $)$ and management responsibility $(0=$ no, $1=$ yes $)$ were included as control variables. These variables are controlled for because studies that examine perceived HRM practices or employee retention have demonstrated that they are associated with such intentions and perceptions (e.g. Dysvik \& Kuvaas, 2008; Koster et al., 2011).

\section{Data Analysis}

Due to the data being self-report and collected at one point in time, procedural and statistical remedies were used to ensure the distinctiveness of the constructs and address the potential impact of common method bias on the study results. Following established recommendations, a) respondents received an email, before completing the questionnaire, explaining the procedures, anonymity, and rights as a research participant, and b) the main study measures were separated and placed in different sections, and filler items as well as different instructions were used to create a psychological separation between the sets of variables (Conway \& Lance, 2010; Podsakoff, MacKenzie, Lee, \& Podsakoff, 2003). To control for the influence of common method bias statistically and to determine how the model fitted the data, a confirmatory factor analysis (CFA) was conducted. Four fit indices were calculated: Chi-square goodness of fit $\left(\chi^{2}\right)$, comparative fit index (CFI), root mean square error of approximation (RMSEA) and standardized root mean square residual (SRMR). CFI should be equal or greater than 0.90; RMSEA and SRMR should be 0.08 or less (Hu \& Bentler 1998; Podsakoff et al., 2003). The CFA 
found that the six latent constructs (i.e. T\&D, job satisfaction, emotional exhaustion, change-related anxiety, employee engagement, intention to stay) were distinct factors as the model had a reasonable fit: $\chi^{2}(237)=2038.09, p<0.001$; $\mathrm{RMSEA}=0.08, \mathrm{CFI}=$ $0.85, \mathrm{SRMR}=0.08$. Although the $\chi^{2} / \mathrm{df}$ ratio (8.60) is higher than the recommended range of 1.00 to 3.00 (Schermelleh-Engel, Moosbrugger, \& Müller, 2003), it is acceptable considering our large sample size (Hair et al., 2009).

To further test for common method variance, we conducted Harman's single factor test, which involves a CFA where all variables are allowed to load onto one general factor. The one-factor model was a poorer fit than the six-factor model $\left(\Delta \chi^{2}(15)\right.$ $=4827.80, p<0.001)$ and did not fit the data well: $\chi^{2}(252)=6865.89, p<0.001$;

$\mathrm{RMSEA}=0.16, \mathrm{CFI}=0.45, \mathrm{SRMR}=0.13$. In addition, alternative nested models were tested to ensure that no other (more parsimonious) alternatives were suitable. Table 2 shows that these models did not fit the data better than the hypothesized six-factor model. Hence, we can conclude that common method bias does not cause major concerns in the present study.

\section{INSERT TABLE 2 HERE}

As the survey was conducted across seven organizations, the data can be considered as being hierarchically structured around two levels: the individual employee $(N=1,191)$ and the organization $(k=7)$. Multilevel modelling (MLM) enables regression analyses to be conducted whilst taking into account these hierarchical structures (Snijders \& Bosker, 2012). It is more robust and precise than standard multiple regression when the data is hierarchically structured, even when no higher level attributes are included as predictors (Bliese \& Hanges, 2004). As recommended by multilevel scholars (Snijders \& Bosker, 2012), we conducted an ANOVA as a pretest to see if there were differences between organizations with regards to the dependent variable (i.e. intent to stay). We 
found that the organizations did differ $-F(6,1184)=65.96, p<.001$ and so we proceeded to testing a multilevel model. To determine the amount of variance that was attributed to the different levels of analysis, the intraclass correlation for each of the firstlevel variables was calculated (Snijders \& Bosker, 2012). For the dependent variable (DV) $18 \%$ of variance was attributed to the between-organizations level; with the predictor variables ranging from $2 \%$ to $22 \%$. Overall these suggest that MLM is warranted as $10 \%$ or more variance of the DV was attributed to the between-groups level (Snijders \& Bosker, 2012). This is in line with other studies which have shown the advantage and utility of using multilevel modelling even when the number of higher level units has been less than the recommended 20 (e.g. Major, Fletcher, Davis, \& Germano, 2008). MLM was conducted using the mixed linear model function in SPSS version 18 (SPSS, 2009). Random intercept models were tested, IGLS estimation was used, and predictor variables were centred on the grand mean; based on the recommendations by Snijders and Bosker (2012). Tests for mediation effects adopted the Monte Carlo Method for Assessing Mediation (MCMAM; Selig \& Preacher, 2008).

\section{Findings}

Table 3 presents the Cronbach's Alpha values, the mean and standard deviation for each scale, and inter-scale correlations for all latent variables in the study. The interscale correlations show the expected direction of association and are all significant at the $p<0.001$ level, except one which is at the $p<0.01$ level.

\section{INSERT TABLE 3 HERE}

The results of the MLM analyses are presented in Table 4. The null model, without any predictor variables, was first conducted to ascertain the baseline $-2 * \log$ likelihood $(-2 * \log )$ and variance figures. 
The second model tested the effects of the control variables on intention to stay. This model was a better fit than the null model $\Delta-2 * \log =55.27, p<0.001$. Women $(\gamma=$ $0.15, p<0.05)$ and older workers $(\gamma=0.17, p<0.001)$ were, on average, more likely to stay with the organization than males and younger employees. Tenure $(\gamma=0.06, p>$ $0.05)$ and management responsibility $(\gamma=0.06, p>0.05)$ were not significantly associated with intention to stay. However, tenure became a significant predictor in the subsequent models; those with long lengths of service were, on average, more likely to stay with the organization than those with short lengths of service.

The third model tested the effects of perceived T\&D on intention to stay. This model was a better fit than the control model: $\Delta-2 * \log =68.72, p<0.001$. Perceived $\mathrm{T} \& \mathrm{D}(\gamma=0.29, p<0.001)$ was positively associated with intention to stay. Therefore, the first condition (of four) needed for mediation was met, i.e. the predictor should be significantly associated with the dependent variable (Baron \& Kenny, 1986). Table 5 shows that perceived T\&D was significantly associated with each of the work attitudes, thus meeting the second condition of mediation, i.e. the predictors are correlated with the mediator (Baron \& Kenny, 1986).

The fourth model in Table 4 tested the effects of the four work attitudes on intention to stay. This model was a better fit than the control model $\Delta-2 * \log =203.90, p$ $<0.001$. Job satisfaction $(\gamma=0.31, p<0.001)$, and employee engagement $(\gamma=0.29, p<$ 0.001) were significantly and positively associated with intention to stay. Change-related anxiety was significantly and negatively associated with intention to stay $(\gamma=-0.07, p<$ 0.05). Therefore, Hypotheses 2, 3, and 4 were fully supported, meeting the third condition needed for mediation, i.e. the mediators should be significantly associated with the dependent variable (Baron \& Kenny, 1986). However, emotional exhaustion was not 
significantly related with intention to stay $(\gamma=-0.03, p>0.05)$, thus Hypothesis 1 was not supported, and as a result Hypothesis 5a (mediation) was also not supported.

The fifth model tested the effects of the work attitudes on intention to stay, whilst taking into account the effects of perceived T\&D. This model was a better fit than the training and development model (model 3): $\Delta-2 * \log =154.95, p<0.001$. The association between perceived T\&D and intention to stay became non-significant $(\gamma=0.07, p>$ 0.05), whereas the associations between the work attitudes and intention to stay remained at similarly significant levels to model 4 , i.e. fulfilling the fourth condition of mediation (Baron \& Kenny, 1986).

To ascertain whether these indirect effects were significant, MCMAM tests were performed (Selig \& Preacher, 2008). MCMAM is a repeated simulation (20,000 repetitions) of $a^{*} b$ and the assumption is that in the case of no mediation effect, $a^{*} b$ would be zero, i.e. mediation should be accepted if the $95 \%$ confidence interval of the indirect effect does not contain zero. The $a$ and $S E$ of $a$ were taken from Table 5; and the $b$ and $S E$ of $b$ were taken from model five in Table 4 for each mediation test. As Table 6 shows, three work attitudes were found to mediate the relationship between perceived $\mathrm{T} \& \mathrm{D}$ and intention to leave: job satisfaction $-a b=0.11$; employee engagement $-a b=$ 0.07; and change-related anxiety- $a b=0.01$. The effect sizes (calculated as the 'completely standardized indirect effect' described by Preacher \& Kelley, 2011) indicated that the indirect effects were small (Cohen, 1988). The strongest mediator was job satisfaction $($ effect size $=0.08)$, followed by employee engagement $($ effect size $=$ 0.05 ), with change-related anxiety as the weakest (effect size $=0.01$ ). Overall, these results confirm Hypotheses 5b, 5c and 5d.

To ascertain whether any of the significant mediators were just as powerful when considered singularly, the multilevel analysis was re-run for the fifth model. Table 7 
shows that each work attitude was significantly related to intention to stay, and that the relationship between perceived T\&D and intention to stay remained significant for all of the work attitudes when each was considered alone, indicating that each attitude partially mediates the relationship between T\&D and intention to stay. Moreover, the full hypothesized model (Model 5 in Table 4) was a better fit than these alternative models: job satisfaction $\Delta-2 * \log =30.90, p<0.001 ;$ emotional exhaustion $\Delta-2 * \log =131.49, p<$ 0.001 ; change-related anxiety $\Delta-2 * \log =136.61, p<0.001$; employee engagement $\Delta$ $2 * \log =87.44, p<0.001$. This supports Hypothesis 6 as the four work attitudes, together, fully mediate the relationship between perceived T\&D and intention to stay.

INSERT TABLE 4 HERE

INSERT TABLE 5 HERE

INSERT TABLE 6 HERE

INSERT TABLE 7 HERE

\section{Discussion}

Our study demonstrates that Russell's (1980) model is a useful way of differentiating various work attitudes, and their potential strength of influence on outcomes, and complements other studies that have utilized an affect-based perspective to understand attitudes (e.g. Bakker \& Oerlemans, 2010; Bakker et al., 2011; Colquitt et al., 2013). Based on Russell's model, we proposed that work attitudes, associated with intention to stay, can be categorized into four main groups: those that are unpleasant and low in activation, those that are unpleasant and high in activation, those that are pleasant and low in activation, and those that 
are pleasant and high in activation. Our findings contribute to HRM research and theory in different ways.

First, our study demonstrates that the relationship between perceived T\&D and intention to stay is fully mediated by different forms of work attitude. We found that job satisfaction and employee engagement, and to some degree (and negatively) changerelated anxiety mediated the relationship between perceived $T \& D$ and intention to stay. Contrary to our predictions, emotional exhaustion was not a mediator. This is one of the first studies to examine a range of mediators in one model of employee retention using an integrated framework of work attitudes. The results show that different work attitudes are associated differently with employee retention, but together fully explained the relationship between T\&D and intention to stay. Hence, future research exploring the mediated link between HRM practices and employee-level outcomes, should consider attitudes under a holistic framework, rather than just singling out individual attitudes.

Second, the results show that job satisfaction and employee engagement may have stronger direct and mediational relationships with intent to stay than emotional exhaustion and change-related anxiety. This indicates that Russell's (1980) distinction between pleasant and unpleasant affect is particularly relevant to understanding the attitudinal processes that link perceived T\&D with employee retention. Perceived T\&D may facilitate employee retention as it is associated with positive attitudinal states rather than with negative attitudinal states. Future research should explore whether the same is true for other types of HRM practices, as there are some that may also have negative or detrimental effects. For example, performance management when focused on control and monitoring is often associated with increased emotional exhaustion (e.g. Brown \& Benson, 2003). Therefore, there is scope to integrate the literature on HRM (e.g. Alfes, Shantz, Truss, \& Soane, 2012; Fletcher, 2016b) with Russell's (1980) model to illustrate 
the different affective pathways present when an employee feels that they have access to different types HRM practices.

Third, with regards to the second dimension of the Russell model our findings suggest that perceived T\&D is associated with both deactivated and activated forms of work attitude, and that those forms of attitudes effect employee retention in similar ways. Specifically, our finding revealed that the mediated effects of job satisfaction and employee engagement were of similar magnitude. This indicates that the pleasant/unpleasant dimension differentiates between the effects of work attitudes on intent to stay more strongly than the activated/deactivated dimension. Future researchers should place more emphasis on the role of positive affect and emotions when attempting to explain how perceptions of HRM can positively impact employee outcomes. Relying on purely cognitive theories, such as social exchange theory, may not give the fullest or most accurate explanations of these mechanisms (Colquitt et al., 2013).

Overall, this study has shown that Russell's (1980; 2003) model is a useful way of organizing work attitudes into an affect-based, neurological framework that can help to explain the link between perceived HRM and employee attitudes/behavioural intentions. In doing so we have advanced research as scholars can categorize work attitudes into a parsimonious and integrated model that enables comparison and evaluation of individual-level processes and relationships. It also brings together previous mediational HRM studies under a single conceptual and empirical framework.

\section{Limitations and areas for future research}

The results should be assessed in light of the study's limitations. First, all variables were measured at the same time-point using self-report data and so causality cannot be established. However, all recommendations put forth by Conway and Lance (2010) were implemented in the present study to mitigate concerns regarding common 
methods bias and additional tests suggest that common method bias did not cause a major concern. Nevertheless, longitudinal and experimental research is needed to confirm the causal order of the relationships.

Second, the data was collected across a five-year period and represents only seven organizations, with a focus on public and voluntary sectors. These issues are particularly salient in light of the fluctuating economic situation as a result of the 2007 global recession (Martin \& Gollan, 2012; Nijssen \& Paauwe, 2012). This may have impacted on the relationships in different ways depending on the timing of each survey. We have accepted this limitation as it was difficult, practically, to collect many complex datasets over a limited time period, but we encourage scholars to collect data from a minimum of 20 organizations across a shorter time span to ensure a strong level of power is obtained (Kreft \& de Leeuw, 1998).

Moreover, prior literature shows that public and private sector employees may differ in their levels of work attitudes and intentions to stay, although findings with regards to which type of employee have more positive attitudes and stronger intentions to stay are somewhat inconsistent (cf., Abualrub et al., 2009; George \& Zakkariya, 2015; Trinchero et al., 2014). It is therefore plausible that our hypothesised relationships differ depending on the sector the organizations belong to. We have addressed this limitation by utilizing multilevel modelling, which separates out the variance at the individual and organizational levels, but we encourage future research to design cross-sector comparative designs to further explore sectoral differences.

Third, while we used an existing questionnaire that had been applied across a range of organizations, the instruments were designed for a specific practical purpose, with many consisting of a small number of items. Moreover, the dependent variable was captured by one item. Although not ideal, a single-item measure can offer a useful, 
pragmatic and valid way of capturing simplistic, concrete psychological constructs, such as intent to stay (Fisher, Matthews, \& Gibbons, 2016). Although we replicated the study with an additional dataset, which demonstrated that all measures showed high levels of reliability and correspondence with other published scales, researchers may want to replicate the study with other alternative measures that include a wider range of items. Related to this, we did not measure affect directly and therefore future research would benefit from including measures of affect as well as of work attitudes to further substantiate and validate our model.

Fourth, we conceptualized and measured perceived T\&D as one overall factor. Although this is in line with other research (e.g. Boon et al., 2011), there may be an important distinction between training and development. Training refers to the acquisition of technical job-specific skills aimed at increasing personal effectiveness whereas development signifies the expansion of generalized skills and career development opportunities aimed at enhancing personal growth (Aguinus \& Kraiger, 2009). This has implications for theory and practice, as technical job-specific skills may have differential effects than generalized skills and career development. For example, Paul and Anantharaman (2003) found that training was most related to higher levels of employee productivity whereas career development was associated most strongly with employee retention. Therefore, treating them as one overall HRM practice may be misleading in terms of management implications. We would welcome future research that separates out the effects and mediation pathways of perceived training and perceived development. We would expect that perceived training triggers deactivated attitudes as the individual expects to receive a certain amount of technical skills training to be able to perform the job effectively; whereas perceived development is likely to elicit activated attitudes as these activities encourage personal growth and mastery. 
Finally, our study focused on retention rather than turnover. The antecedents of retention may be different to those of turnover and so future research could compare the attitudinal mechanisms of retention and turnover. We would expect that the antecedents of retention are likely to be 'pull' factors, such as positive experiences and job resources, whereas the antecedents of turnover are likely to be 'push' factors, such as negative experiences and excessive job demands (Scanlan, Still, Stewart, \& Croaker, 2010).

\section{Implications for practice and conclusion}

This study indicates that during periods of economic instability and organizational change, investment in T\&D is important. During such periods HRM practitioners should focus on developing and implementing a range of $\mathrm{T} \& \mathrm{D}$ practices that motivate and energize employees. This supports Nijssen and Paauwe's (2012) argument that implementing $\mathrm{T} \& \mathrm{D}$ during turbulent economic times is important for achieving organizational agility. The evidence that job satisfaction and employee engagement are particularly important mediators of the relationship between perceived $\mathrm{T} \& \mathrm{D}$ and intention to stay support the measurement and monitoring of such attitudes as part of a human capital management strategy for organizations undergoing change (Martin \& Gollan, 2012). Many organizations now undertake annual employee surveys and benchmarking activities to understand how engaged their employees are (Fletcher $\&$ Robinson, 2014). They are often used to identify areas for managerial action so that human capital within the organization is optimized (Harter et al., 2002). The current study suggests that such surveys can also be used by training practitioners as the findings highlight how employee engagement is an important outcome of T\&D. Therefore, practitioners could assess and monitor employee engagement levels via questionnaire measures to identify opportunities for $T \& D$ and when implementing/evaluating $T \& D$ practices (see Fletcher \& Robinson, 2014). For example, practitioners could examine the 
links between different types of T\&D (e.g. formal training, courses leading to a qualification, informal development opportunities) and work attitudes to help them to identify where to position scarce resources.

To conclude, this paper has demonstrated that perceived T\&D is positively associated with intention to stay, and that this relationship is fully mediated by three different forms of work attitude: job satisfaction, employee engagement, and changerelated anxiety. Building on Russell's $(1980 ; 2003)$ model of core affect, the study indicates that perceived $T \& D$ is associated with intention to stay via pleasant forms of work attitude that act to motivate and energize rather than via unpleasant forms of work attitude that act to impair wellbeing. Overall, our study suggests that future research linking perceived HRM practices to employee-level outcomes should incorporate a broader range of attitudes to understand in more detail the mechanisms through which these perceptions are related to employee attitudes and behaviour.

\section{References}

AbuAlRub, R. F., Omari, F. H., \& Al-Zaru, I. M. (2009). Support, satisfaction and retention among Jordanian nurses in private and public hospitals. International Nursing Review, 56, 326-332. doi: 10.1111/j.1466-7657.2009.00718.x

Aguinis, H., \& Kraiger, K. (2009). Benefits of training and development for individuals and teams, organizations, and society. Annual Review of Psychology, 60, 451474. doi:10.1146/annurev.psych.60.110707.163505

Alarcon, G.M. (2011). A meta-analysis of burnout with job demands, resources and attitudes. Journal of Vocational Behavior, 29, 549-562. doi:10.1016/j.jvb.2011. 03.007

Alfes, K., Shantz, A., Truss, C., \& Soane, E.C. (2012). The link between perceived human resource management practices, engagement and employee behavior: a moderated mediation model. The International Journal of Human Resource Management, 24, 330-351. doi:10.1080/09585192.2012.679950 
Bailey, C., Madden, A., Alfes, K., \& Fletcher, L. (2015). The meaning, antecedents and outcomes of employee engagement: a narrative evidence synthesis. International Journal of Management Reviews, online first.. doi: 10.1111/ijmr.12077

Bakker, A. B., \& Oerlemans, W. (2011). Subjective well-being in organizations. In K. Cameron and G. Spreitzer (eds.), The Oxford Handbook of Positive Organizational Scholarship (pp.178-189). Oxford: Oxford University Press.

Bakker, A. B., Albrecht, S. L., \& Leiter, M. P. (2011). Work engagement: Further reflections on the state of play. European Journal of Work and Organizational Psychology, 20, 74-88. doi: 10.1080/1359432X.2010.546711

Baron, R.M., \& Kenny, D.A. (1986). The moderator-mediator variable distinction in social psychological research: Conceptual, strategic, and statistical considerations. Journal of Personality and Social Psychology, 51, 1173-1182. doi:10.1037/00223514.51.6.1173

Baruch, Y., \& Lambert, R. (2007). Organizational anxiety: applying psychological concepts to organizational theory. Journal of Managerial Psychology, 22, 84-99. doi: 10.1108/02683940710721956

Bergkvist, L., \& Rossiter, J.R. (2007). The predictive validity of multiple-item versus single-item measures of the same construct. Journal of Marketing Research, 44, 175-184. doi:10.1509/jmkr.44.2.175

Bernerth, J. B., Walker, H. J., \& Harris, S. G. (2011). Change fatigue: Development and initial validation of a new measure. Work \& Stress, 25, 321-337. doi:10.1080/ 02678373.2011 .634280

Bliese, P.D. and Hanges, P.J. (2004). Being both too liberal and too conservative: the perils of treating grouped data as though they were independent. Organizational Research Methods, 7, 400-417. doi: 10.1177/1094428104268542

Boon, C., Den Hartog, D. N., Boselie, P., \& Paauwe, J. (2011). The relationship between perceptions of HR practices and employee outcomes: examining the role of person-organization and person-job fit. The International Journal of Human Resource Management, 22, 138-162. doi:10.1080/09585192.2011.538978

Brown, M., \& Benson, J. (2003). Rated to exhaustion? Reactions to performance appraisal processes. Industrial Relations Journal, 34, 67-81. doi: 10.1111/1468 2338.00259 
Burke, R. J., Singh, P., \& Fiksenbaum, L. (2010). Work intensity: Potential antecedents and consequences. Personnel Review, 39, 347-360. doi:10.1108/00483481011030 539

Cohen, J. (1988). Statistical power analysis for the behavioral sciences $2^{\text {nd }}$ edition. New York, USA: Academic Press.

Colquitt, J. A., Scott, B. A., Rodell, J. B., Long, D. M., Zapata, C. P., Conlon, D. E., \& Wesson, M. J. (2013). Justice at the millennium, a decade later: A meta-analytic test of social exchange and affect-based perspectives. Journal of Applied Psychology, 98, 199-236. doi:10.1037/a0031757

Conway, J., \& Lance, C. (2010). What reviewers should expect from authors regarding common method bias in organizational research. Journal of Business and Psychology, 25, 325-33. doi:10.1007/s10869-010-9181-6

Cunningham, G.B. (2006). The relationships among commitment to change, coping with change, and turnover intentions. European Journal of Work and Organizational Psychology, 15, 29-45. doi: 10.1080/13594320500418766

Dysvik, A., \& Kuvaas, B. (2008). The relationship between perceived training opportunities, work motivation and employee outcomes. International Journal of Training and Development, 12, 138-157. doi:10.1111/j.1468-2419.2008.00301.x

Eagly, A.H. and Chaiken, S. (2007). The advantages of an inclusive definition of attitude. Social Cognition, 25, 582-602. doi: 10.1521/soco.2007.25.5.582

Fisher, G. G., Matthews, R. A., \& Gibbons, A. M. (2016). Developing and investigating the use of single-item measures in organizational research. Journal of Occupational Health Psychology, 21, 3-23. doi: 10.1037/a0039139

Fletcher, L. (2016a). Training perceptions, engagement, and performance: comparing work engagement and personal role engagement. Human Resource Development International,19, 4-26.. doi:10.1080/13678868.2015.1067855

Fletcher, L. (2016b). How can personal development lead to increased engagement? The roles of meaningfulness and perceived line manager relations. The International Journal of Human Resource Management. online first publication. doi: 10.1080/09585192.2016.1184177

Fletcher, L., \& Robinson, D. (2014). Measuring and understanding engagement. In C. Truss, R. Delbridge, K. Alfes, A. Shantz, and E. Soane (Eds.), Employee Engagement in Theory and Practice (pp.587-627). London: Routledge. 
George, E. \& Zakkairya, K.A. (2015). Job related stress and job satisfaction: a comparative study among bank employees. Journal of Management Development, 34, 316-329. doi: 10.1108/JMD-07-2013-0097

Griffeth, R. W., Hom, P.W., \& Gaertner, S. (2000). A meta-analysis of antecedents and correlates of employee turnover: Update, moderator tests, and research implications for the next millennium. Journal of Management, 26, 463-488. doi: $10.1177 / 014920630002600305$

Guest, D. E. (2002). Human resource management, corporate performance and employee wellbeing: Building the worker into HRM. The Journal of Industrial Relations, 44, 335-358. doi:10.1111/1472-9296.00053

Hair, J. F., Black, W. C., Babin, B. J., Anderson, R. E., \& Tatham, R. L. (2005). Multivariate Data Analysis ( $6^{\text {th }}$ ed.). Upper Saddle River, NJ: Pearson Prentice Hall.

Harrison, D. A., Newman, D. A., \& Roth, P. L. (2006). How important are job attitudes? Meta-analytic comparisons of integrative behavioral outcomes and time sequences. Academy of Management Journal, 49, 305-325. doi:10.5465/AMJ. 2006.20786077

Harter, J. K., Schmidt, F. L., \& Hayes, T. L. (2002). Business-unit-level relationship between employee satisfaction, employee engagement, and business outcomes: a meta-analysis. Journal of Applied Psychology, 87, 268-279. doi:10.1037/00219010.87.2.268

Hobfoll, S. E. (1989). Conservation of resources: A new attempt at conceptualizing stress. American Psychologist, 44, 513-524. doi:10.1037/0003-066X.44.3.513

Hu, L., \& Bentler, P.M. (1998). Fit indices in covariance structure modeling: Sensitivity to underparameterized model misspecification. Psychological Methods, 3, 424445. doi:10.1080/10705519909540118

Jenkins, S., \& Delbridge, R. (2013). Context matters: Examining 'soft' and 'hard' approaches to employee engagement in two workplaces. The International Journal of Human Resource Management, 24, 2670-2691. doi:10.1080/ 09585192.2013.770780

Jensen, J. M., Patel, P. C., \& Messersmith, J. G. (2013). High-performance work systems and job control consequences for anxiety, role overload, and turnover 
intentions. Journal of Management, 39, 1699-1724. doi:10.1177/0149206311419 663

Koster, F., de Grip, A., \& Fouarge, D. (2011). Does perceived support in employee development affect personnel turnover?. The International Journal of Human Resource Management, 22, 2403-2418. doi:10.1080/09585192.2011.584404

Kreft, I. G. G., \& De Leeuw, J. (1998). Introducing Multilevel Modeling. Newbury Park, CA: Sage

Langford, P. H. (2009). Measuring organizational climate and employee engagement: Evidence for a 7 Ps model of work practices and outcomes. Australian Journal of Psychology, 61, 185-198. doi:10.1080/00049530802579481

Lee, C.H., \& Bruvold, N.T. (2003). Creating value for employees: Investment in employee development. The International Journal of Human Resource Management, 14, 986-1000. doi:10.1080/0958519032000106173

Locke, E. A. (1976). The nature and causes of job satisfaction. In M.D. Dunnette (Ed.), Handbook of industrial and organizational psychology (pp.1297-1349). Chicago, USA: Rand McNally.

MacCormick, J. S., \& Parker, S. K. (2010). A multiple climates approach to understanding business unit effectiveness. Human Relations, 63, 1771-1806. doi: $10.1177 / 0018726710365090$

Major, D.A., Fletcher, T.D., Davis, D.D., \& Germano, L.M. (2008). The influence of work-family culture and workplace relationships on work interference with family: a multilevel model. Journal of Organizational Behavior, 29, 881-897. doi: $10.1002 /$ job.502

Martin, G., \& Gollan, P.J. (2012). Corporate governance and strategic human resources management in the UK financial services sector: the case of the RBS. The International Journal of Human Resource Management, 23, 3295-3314. doi: $10.1080 / 09585192.2012 .689159$

Maslach, C., Schaufeli, W. B., \& Leiter, M. P. (2001). Job burnout. Annual Review of Psychology, 52, 397-422. doi:10.1146/annurev.psych.52.1.397

Newman, A., Thanacoody, R., \& Hui, W. (2011). The impact of employee perceptions of training on organizational commitment and turnover intentions: a study of multinationals in the Chinese service sector. The International Journal of Human Resource Management, 22, 1765-1787. doi: 10.1080/09585192.2011.565667 
Ng, T.W., \& Butts, M.M. (2009). Effectiveness of organizational efforts to lower turnover intentions the moderating role of employee locus of control. Human Resource Management, 48, 289-310. doi:10.1002/hrm.20280

Nijssen, M., \& Paauwe, J. (2012). HRM in turbulent times: how to achieve organizational agility?. The International Journal of Human Resource Management, 23, 3315-3335. doi: 10.1080/09585192.2012.689160

Nishii, L. H., Lepak, D. P., \& Schneider, B. (2008). Employee attributions of the "why" of HR practices: Their effects on employee attitudes and behaviors, and customer satisfaction. Personnel Psychology, 61, 503-545. doi:10.1111/j.17446570.2008.00121.x

Parker, S.K., \& Griffin, M.A. (2011). Understanding active psychological states: Embedding engagement in a wider nomological net and closer attention to performance. European Journal of Work and Organizational Psychology, 20, 6067. doi:10.1080/1359432X.2010.532869

Paul, A. K. \& Anantharaman, R. N. (2003). Impact of people management practices on organizational performance: analysis of a causal model. The International Journal of Human Resource Management, 14, 1246-1266. doi:10.1080/09585190 32000145648

Podsakoff, P. M., MacKenzie, S. B. , Lee, J. Y., \& Podsakoff, N. P. (2003). Common method biases in behavioral research: A critical review of the literature and recommended remedies. Journal of Applied Psychology, 88, 879-903. doi:10.1037/0021-9010.88.5.879

Preacher, K.J., \& Kelley, K. (2011). Effect size measures for mediation models: Quantitative strategies for communicating indirect effects. Psychological Methods, 16, 93-115. doi:10.1037/a0022658

Robertson, I. T., Cooper, C. L., Sarkar, M., \& Curran, T. (2015). Resilience training in the workplace from 2003 to 2014: A systematic review. Journal of Occupational and Organizational Psychology, 88, 533-562. doi: 10.1111/joop.12120

Robinson, D., Perryman, S., \& Hayday, S. (2004). The drivers of employee engagement. Report 408, Brighton, UK: Institute for Employment Studies.

Robinson, D., Hooker, H., \& Hayday, S. (2007). Engagement: The continuing story. Report 447, Brighton, UK: Institute for Employment Studies.

Russell, J.A. (1980). A Circumplex Model of Affect. Journal of Personality and Social Psychology, 39, 1161-1178. doi:10.1037/h0077714 
Russell, J. A. (2003). Core affect and the psychological construction of emotion. Psychological Review, 110, 145-172. doi:10.1037/0033-295X.110.1.145

Saks, A. M. (2006). Antecedents and consequences of employee engagement. Journal of Managerial Psychology, 21, 600-619. doi:10.1108/02683940610690169

Scanlan, K.N., Still, M., Stewart, K., \& Croaker, J. (2010). Recruitment and retention issues for occupational therapists in mental health: Balancing the pull and the push. Australian Occupational Therapy Journal, 57, 102-110. doi: 10.1111/j.1440-1630.2009.00814.x

Schaufeli, W.B. (2014). What is engagement?. In Truss, C, R. Delbridge, K. Alfes, A. Shantz, and E. Soane (Eds.), Employee Engagement in Theory and Practice (pp.15-35). London UK: Routledge

Schermelleh-Engel, K., Moosbrugger, H., \& Müller, H. (2003). Evaluating the fit of structural equation models: tests of significance and descriptive goodness-of-fit measures. Methods of Psychological Research Online, 8, 23-74.

Schleicher, D. J., Hansen, D., \& Fox, K. E. (2010). Job attitudes and work values. In S. Zedeck (Ed.), APA handbook of industrial and organizational psychology vol. 3 (pp.137-189). Washington DC, USA: American Psychological Association. ISBN:978-1-4338-0727-5

Selig , J.P., \& Preacher, K.J. (2008), Monte carlo method for assessing mediation: An interactive tool for creating confidence intervals for indirect effects [Computer software]. Available at: http://quantpsy.org/.

Snijders, T.A.B., \& Bosker, R.J. (2012). Multilevel analysis: an introduction to basic and advanced multilevel modelling $2^{\text {nd }}$ Edition, London, UK: Sage Publications. ISBN: 978-1849202015

SPSS (2009). PASW statistics for windows. Version 18.0. [Computer software]. Chicago, USA. SPSS Inc.

Tett, R. P., and Meyer, J. P. (1993). Job satisfaction, organizational commitment, turnover intention, and turnover: path analyses based on meta-analytic findings. Personnel Psychology, 46, 259-293. doi:10.1111/j.17446570.1993.tb00874.x

Trinchero, E., Borgonovi, E., \& Farr-Wharton, B. (2014). Leader-member exchange, affective commitment, engagement, wellbeing, and intention to leave: public versus private sector Italian nurses. Public Money \& Management, 34, 381-388. doi: 10.1080/09540962.2014.962361 
Vigoda-Gadot, E., \& Kapun, D. (2005). Perceptions of politics and perceived performance in public and private organisations: a test of one model across two sectors. Policy \& Politics, 33, 251-276. doi: 10.1332/0305573053870185

Warr, P., Bindl, U. K., Parker, S. K., \& Inceoglu, I. (2014). Four-quadrant investigation of job-related affects and behaviors. European Journal of Work and Organizational Psychology, 23, 342-363. doi:10.1080/1359432X.2012.744449

Wright, P.M., \& Boswell, W.R. (2002). Desegregating HRM: a review and synthesis of micro and macro human resource management research. Journal of Management, 28, 247-276. doi:10.1177/014920630202800302

Wright, P. M., \& Nishii, L. H. (2007). Strategic HRM and organizational behavior: Integrating multiple levels of analysis (CAHRS Working Paper \#07-03). Ithaca, NY: Cornell University. http://digitalcommons.ilr.cornell.edu/cahrswp/468 


\section{Appendix 1: Scales and items used in the study}

\section{Training and Development}

I am encouraged to develop new skills

My line manager takes employee development seriously

I have many opportunities for training and development

\section{Job satisfaction}

I find real enjoyment in my job

I am seldom bored with my job

Overall, I am satisfied with my job

\section{Emotional exhaustion}

I have felt emotionally drained by my work

I feel burned out by my work

I have felt under constant strain recently

\section{Change-related anxiety}

I sometimes feel overwhelmed by the pace of change here

The pace of change is too fast here

\section{Employee engagement}

I speak highly of this organization to my friends

I would be happy for my friends and family to use this organization's products/services

This organization is known as a good employer

This organization has a good reputation generally

I proud to tell others that I am a part of this organization

This organization really inspires the very best in me in the way of performance

I find that my values and the organization's are very similar

I always do more than is actually required

I try to help others in this organization whenever I can

I try to keep abreast of current developments in my area

I volunteer for things that contribute to the organization's objectives

I frequently make suggestions to improve the work of my team/department

Intention to stay 'Which of the following statements most reflect your current intentions? 1- Plan to leave as soon as possible, 2- Likely to leave within the next year, 3Likely to stay for at least another year, 4- Plan to stay for the foreseeable future'. 
Table 1. Distribution of sector, organizational size, gender, age, tenure and managerial responsibility

\begin{tabular}{|c|c|c|c|c|c|c|c|}
\hline & Industry & Sector & Size & $\%$ Female & $\begin{array}{l}\text { Median } \\
\text { Age } \\
\text { Category }\end{array}$ & $\begin{array}{l}\text { Median } \\
\text { Tenure }\end{array}$ & $\begin{array}{l}\text { \% Managerial } \\
\text { Responsibility }\end{array}$ \\
\hline $\begin{array}{l}\text { Org } \\
1\end{array}$ & $\begin{array}{l}\text { Scientific } \\
\text { research }\end{array}$ & Voluntary & Large & 64.2 & $\begin{array}{c}30-39 \\
\text { years }\end{array}$ & $\begin{array}{l}4-7 \\
\text { years }\end{array}$ & 22.8 \\
\hline $\begin{array}{l}\text { Org } \\
2\end{array}$ & Education & Voluntary & Small & 42.3 & $\begin{array}{c}40-49 \\
\text { years }\end{array}$ & $\begin{array}{l}4-7 \\
\text { years }\end{array}$ & 53.5 \\
\hline $\begin{array}{l}\text { Org } \\
3\end{array}$ & $\begin{array}{c}\text { Local } \\
\text { government }\end{array}$ & Public & Medium & 45.5 & $\begin{array}{c}40-49 \\
\text { years }\end{array}$ & $7+$ years & 19.3 \\
\hline $\begin{array}{l}\text { Org } \\
4\end{array}$ & Healthcare & Public & Large & 78.8 & $\begin{array}{l}40-49 \\
\text { years }\end{array}$ & $\begin{array}{l}4-7 \\
\text { years }\end{array}$ & 7.6 \\
\hline $\begin{array}{l}\text { Org } \\
5\end{array}$ & $\begin{array}{l}\text { Regulatory } \\
\text { body }\end{array}$ & Public & Small & 71.4 & $\begin{array}{c}40-49 \\
\text { years }\end{array}$ & $\begin{array}{l}1-3 \\
\text { years }\end{array}$ & 61.2 \\
\hline $\begin{array}{l}\text { Org } \\
6\end{array}$ & $\begin{array}{c}\text { Event } \\
\text { management }\end{array}$ & Voluntary & Small & 33.3 & $<30$ years & $\begin{array}{l}1-3 \\
\text { years }\end{array}$ & 45.1 \\
\hline $\begin{array}{l}\text { Org } \\
7\end{array}$ & Technology & Private & Large & 16.6 & $\begin{array}{c}30-39 \\
\text { years }\end{array}$ & $7+$ years & 0.0 \\
\hline $\begin{array}{l}\chi^{2} \\
\text { (df) }\end{array}$ & & & & $\begin{array}{c}274.55^{* * * *} \\
(6)\end{array}$ & $\begin{array}{c}165.42 * * * \\
(18)\end{array}$ & $\begin{array}{c}272.89 * * * \\
(18)\end{array}$ & $218.41 * * *(6)$ \\
\hline
\end{tabular}

Note: ${ }^{*} p<0.05,{ }^{* *} p<0.01, * * * p<0.001$ 
Table 2. CFA results of 6-factor model and alternative 5-, 4-, 3-, 2- and 1- factor models

\begin{tabular}{|c|c|c|c|c|c|c|}
\hline & $\begin{array}{l}\text { Chi-Square } \\
\chi^{2}(d f) / \Delta \chi^{2}\end{array}$ & $A I C$ & $B I C$ & RMSEA & $C F I$ & SRMR \\
\hline 6 factor model & 2038.09 (237) / 59.41*** & 53949.83 & 54371.20 & 0.08 & 0.85 & 0.08 \\
\hline $\begin{array}{l}\text { Alternative } 5 \text { factor } \\
\text { model }\end{array}$ & $\begin{array}{l}2097.50(242) / \\
832.33 * * *\end{array}$ & 54001.24 & 54403.02 & 0.09 & 0.84 & 0.08 \\
\hline $\begin{array}{l}\text { Alternative } 4 \text { factor } \\
\text { model }\end{array}$ & $\begin{array}{l}2929.83(246) / \\
580.74 * * *\end{array}$ & 54825.57 & 55207.75 & 0.11 & 0.78 & 0.09 \\
\hline $\begin{array}{l}\text { Alternative } 3 \text { factor } \\
\text { model }\end{array}$ & $\begin{array}{l}3510.57(249) / \\
1264.87 * * *\end{array}$ & 55400.31 & 55767.79 & 0.12 & 0.73 & 0.10 \\
\hline $\begin{array}{l}\text { Alternative } 2 \text { factor } \\
\text { model }\end{array}$ & $\begin{array}{l}4775.44(251) / \\
2090.45^{* * *}\end{array}$ & 56661.18 & 57018.86 & 0.14 & 0.63 & 0.10 \\
\hline $\begin{array}{l}\text { Alternative } 1 \text { factor } \\
\text { model }\end{array}$ & $6865.89(252)$ & 58749.63 & 59102.41 & 0.16 & 0.45 & 0.13 \\
\hline
\end{tabular}

$* p<0.05, * * p<0.01, * * * p<0.001$

Note: 5-factor $=\mathrm{a}$ ) intention to stay and engagement, b) perceived T\&D, c) emotional exhaustion, d) change-related anxiety, e) satisfaction; 4-factor = a) intention to stay and engagement, b) satisfaction, c) perceived T\&D, d) emotional exhaustion and change-related anxiety; 3 -factor $=$ a) intent to stay and engagement, b) perceived T\&D and satisfaction, c) emotional exhaustion and change-related anxiety; 2factor $=a$ ) intent to stay, engagement, perceived T\&D and satisfaction, b) change-related anxiety and emotional exhaustion. 
Table 3. Descriptive statistics and correlations between variables at the individual level of analysis

\begin{tabular}{lllllllllllll}
\hline & Mean & \multicolumn{1}{c}{$S D$} & \multicolumn{1}{c}{1} & 2 & 3 & 4 & 5 & 6 & 7 & 8 & 9 & 10 \\
\hline 1 Gender & 0.52 & 0.50 & $(-)$ & & & & & & & & \\
2 Age & 2.52 & 1.00 & -.04 & $(-)$ & & & & & & & \\
3 Tenure & 3.05 & 0.94 & $-.12^{* *}$ & $.39^{* *}$ & $(-)$ & & & & & & \\
4 Managerial Responsibility & 0.16 & 0.37 & .00 & $.16^{* *}$ & -.01 & $(-)$ & & & & & \\
5 Perceived T\&D & 3.30 & 0.79 & .01 & .00 & $-.06^{*}$ & $.13^{* *}$ & $(.82)$ & & & & & \\
6 Job Satisfaction & 3.69 & 0.87 & -.01 & $.09^{* *}$ & .02 & $.08^{* *}$ & $.35^{* * *}$ & $(.91)$ & & & & \\
7 Emotional Exhaustion & 2.74 & 0.95 & $.15^{* * *}$ & .01 & $.12^{* *}$ & -.01 & $-.16^{* * *}$ & $-.18^{* * *}$ & $(.91)$ & & \\
8 Change-Related Anxiety & 3.02 & 1.04 & $-.26^{* * *}$ & -.02 & $.15^{* * *}$ & $-.06^{*}$ & $-.10^{* * *}$ & $-.08^{* *}$ & $.55^{* * *}$ & $(.88)$ & \\
9 Employee Engagement & 3.57 & 0.53 & -.02 & .01 & $-.14^{* * *}$ & $.21^{* * *}$ & $.39^{* * *}$ & $.44^{* * *}$ & $-.28^{* * *}$ & $-.10^{* * *}$ & $(.84)$ & \\
10 Intention to Stay & 3.14 & 1.11 & $.15^{* * *}$ & $.16^{* *}$ & $.07^{*}$ & $.10^{* *}$ & $.21^{* * *}$ & $.33^{* * *}$ & $-.29^{* * *}$ & $-.18^{* * *}$ & $.31^{* * *}$ & $(-)$ \\
\hline
\end{tabular}

Note: $N=1,191 . * p<0.05, * * p<0.01, * * * \mathrm{p}<0.001$. Cronbach's Alphas for each scale are given in parentheses 
Table 4. Multilevel models predicting intention to stay

\begin{tabular}{|c|c|c|c|c|c|c|c|c|c|c|c|c|c|c|c|}
\hline & \multicolumn{3}{|c|}{ Model 1: Null } & \multicolumn{3}{|c|}{ Model 2: Control Variables } & \multicolumn{3}{|c|}{$\begin{array}{c}\text { Model 3: Training \& } \\
\text { Development }\end{array}$} & \multicolumn{3}{|c|}{ Model 4: Work Attitudes } & \multicolumn{3}{|c|}{$\begin{array}{c}\text { Model 5: Full } \\
\text { Hypothesized Model }\end{array}$} \\
\hline & Est. & SE & $\mathrm{t}$ & Est. & SE & $\mathrm{t}$ & Est. & SE & $\mathrm{t}$ & Est. & SE & $\mathrm{t}$ & Est. & SE & $\mathrm{t}$ \\
\hline Intercept & 3.24 & 0.18 & 18.43 & 2.38 & 0.22 & $10.79 * * *$ & 2.35 & 0.21 & $11.29 * * *$ & 2.42 & 0.21 & $11.55^{* * *}$ & 2.41 & 0.21 & $11.56^{* * *}$ \\
\hline Gender & & & & 0.15 & 0.06 & $2.47 *$ & 0.16 & 0.06 & $2.59 * *$ & 0.13 & 0.06 & $2.26^{*}$ & 0.12 & 0.06 & $2.17^{*}$ \\
\hline Age & & & & 0.17 & 0.03 & $5.49 * * *$ & 0.17 & 0.03 & $5.49 * * *$ & 0.13 & 0.03 & $4.39 * * *$ & 0.13 & 0.03 & $4.60 * * *$ \\
\hline Tenure & & & & 0.06 & 0.03 & 1.88 & 0.08 & 0.03 & $2.45^{*}$ & 0.10 & 0.03 & $3.02 * *$ & 0.10 & 0.03 & $3.05 * *$ \\
\hline $\begin{array}{l}\text { Management } \\
\text { Responsibility }\end{array}$ & & & & 0.06 & 0.08 & 0.69 & -0.01 & 0.08 & 0.08 & -0.02 & 0.08 & 0.27 & -0.02 & 0.08 & 0.31 \\
\hline $\begin{array}{l}\text { Perceived } \\
\text { T\&D }\end{array}$ & & & & & & & 0.29 & 0.03 & $8.41 * * *$ & & & & 0.07 & 0.04 & 1.94 \\
\hline $\begin{array}{l}\text { Job } \\
\text { Satisfaction }\end{array}$ & & & & & & & & & & 0.31 & 0.03 & $9.31 * * *$ & 0.29 & 0.03 & $8.71 * * *$ \\
\hline $\begin{array}{l}\text { Emotional } \\
\text { exhaustion }\end{array}$ & & & & & & & & & & -0.03 & 0.03 & 0.99 & -0.03 & 0.03 & 0.94 \\
\hline $\begin{array}{l}\text { Change-related } \\
\text { Anxiety }\end{array}$ & & & & & & & & & & -0.07 & 0.04 & $2.10^{*}$ & -0.07 & 0.03 & $2.08^{*}$ \\
\hline $\begin{array}{l}\text { Employee } \\
\text { Engagement }\end{array}$ & & & & & & & & & & 0.29 & 0.06 & $5.04 * * *$ & 0.26 & 0.06 & $4.37 * * *$ \\
\hline $\begin{array}{l}-2 * \log \\
\text { likelihood }\end{array}$ & \multicolumn{3}{|l|}{3316.28} & \multicolumn{3}{|c|}{$3261.01 * * *$} & \multicolumn{3}{|c|}{$3192.29 * * *$} & \multicolumn{3}{|c|}{$3057.41 * * *$} & \multicolumn{3}{|c|}{$3037.34 * * *$} \\
\hline $\begin{array}{l}\text { Variance } \\
\text { between-orgs }\end{array}$ & \multicolumn{3}{|l|}{.20} & \multicolumn{3}{|l|}{.19} & \multicolumn{3}{|l|}{.16} & \multicolumn{3}{|l|}{.18} & \multicolumn{3}{|l|}{.18} \\
\hline $\begin{array}{l}\text { Variance } \\
\text { within-orgs }\end{array}$ & \multicolumn{3}{|l|}{.93} & \multicolumn{3}{|l|}{.89} & \multicolumn{3}{|l|}{.84} & \multicolumn{3}{|l|}{.75} & \multicolumn{3}{|l|}{.74} \\
\hline
\end{tabular}

Note: Level $1 N=1,191$, Level $2 k=7$. $* p<0.05, * * p<0.01, * * * p<0.001$ 
Table 5. Multilevel models predicting job satisfaction, emotional exhaustion, change-related anxiety and employee engagement

\begin{tabular}{|c|c|c|c|c|c|c|c|c|c|c|c|c|}
\hline & \multicolumn{3}{|c|}{$\begin{array}{l}\text { Predicting Job } \\
\text { Satisfaction }\end{array}$} & \multicolumn{3}{|c|}{$\begin{array}{c}\text { Predicting Emotional } \\
\text { Exhaustion }\end{array}$} & \multicolumn{3}{|c|}{$\begin{array}{l}\text { Predicting Change- } \\
\text { Related Anxiety }\end{array}$} & \multicolumn{3}{|c|}{$\begin{array}{c}\text { Predicting Employee } \\
\text { Engagement }\end{array}$} \\
\hline & Est. & SE & $\mathrm{t}$ & Est. & $\mathrm{SE}$ & $\mathrm{t}$ & Est. & SE & $\mathrm{t}$ & Est. & $\mathrm{SE}$ & $\mathrm{t}$ \\
\hline Intercept & 3.44 & 0.13 & $27.26 * * *$ & 2.80 & 0.19 & $14.74 * * *$ & 2.99 & 0.22 & $13.58 * * *$ & 3.65 & 0.09 & $40.97 * * *$ \\
\hline Gender & 0.02 & 0.05 & 0.35 & -0.10 & 0.06 & 1.74 & -0.16 & 0.06 & $2.60 * *$ & 0.00 & 0.03 & 0.12 \\
\hline Age & 0.08 & 0.03 & $3.12 * *$ & -0.06 & 0.03 & 1.94 & -0.07 & 0.03 & $2.45^{*}$ & 0.04 & 0.01 & $2.55^{* *}$ \\
\hline Tenure & 0.00 & 0.03 & 0.14 & 0.06 & 0.03 & 1.86 & 0.06 & 0.03 & 1.70 & -0.06 & 0.02 & $3.62 * * *$ \\
\hline $\begin{array}{l}\text { Management } \\
\text { Responsibility }\end{array}$ & 0.07 & 0.07 & 1.05 & 0.32 & 0.08 & $4.22 * * *$ & 0.29 & 0.08 & $3.58 * * *$ & 0.14 & 0.04 & $3.59 * * *$ \\
\hline $\begin{array}{l}\text { Perceived } \\
\text { T\&D }\end{array}$ & 0.38 & 0.03 & $13.08 * * *$ & -0.18 & 0.03 & $5.84 * * *$ & -0.11 & 0.03 & $3.25 * * *$ & 0.28 & 0.02 & $16.25 * * *$ \\
\hline $\begin{array}{l}-2 * \log \\
\text { likelihood }\end{array}$ & \multicolumn{3}{|c|}{2858.92} & \multicolumn{3}{|c|}{3011.87} & \multicolumn{3}{|c|}{3057.16} & \multicolumn{3}{|c|}{1481.01} \\
\hline $\begin{array}{l}\text { Variance } \\
\text { between-orgs }\end{array}$ & \multicolumn{3}{|l|}{.01} & \multicolumn{3}{|l|}{.13} & \multicolumn{3}{|l|}{.20} & \multicolumn{3}{|l|}{.02} \\
\hline $\begin{array}{l}\text { Variance } \\
\text { within-orgs }\end{array}$ & \multicolumn{3}{|l|}{.65} & \multicolumn{3}{|l|}{.73} & \multicolumn{3}{|l|}{.83} & \multicolumn{3}{|l|}{.20} \\
\hline
\end{tabular}

Note: Level $1 N=1,191$, Level $2 k=7 ; * p<0.05, * * p<0.01, * * * p<0.001$ 
Table 6. MCMAM analyses examining the mediation effects of work attitudes on the perceived training \& development-intention to stay relationship

\begin{tabular}{|c|c|c|c|c|c|c|c|c|}
\hline Mediator & $a / S E$ & $b / S E$ & $a * b$ & $\begin{array}{l}\text { Lower } \\
\text { Bound }\end{array}$ & $\begin{array}{l}\text { Upper } \\
\text { Bound }\end{array}$ & $c^{\prime}$ & $c$ & Effect Size \\
\hline $\begin{array}{l}\text { Job } \\
\text { Satisfaction }\end{array}$ & $0.38 / 0.03$ & $0.29 / 0.03$ & 0.11 & 0.0798 & 0.1353 & 0.07 & 0.18 & 0.08 \\
\hline $\begin{array}{l}\text { Emotional } \\
\text { Exhaustion }\end{array}$ & $\begin{array}{l}-0.18 / \\
0.03\end{array}$ & $-0.03 / 0.03$ & 0.00 & -0.0066 & 0.0167 & 0.07 & 0.06 & 0.00 \\
\hline $\begin{array}{l}\text { Change- } \\
\text { Related } \\
\text { Anxiety }\end{array}$ & $\begin{array}{l}-0.11 / \\
0.03\end{array}$ & $-0.07 / 0.03$ & 0.01 & 0.0008 & 0.0174 & 0.07 & 0.07 & 0.01 \\
\hline $\begin{array}{l}\text { Employee } \\
\text { Engagement }\end{array}$ & $0.28 / 0.02$ & $0.26 / 0.06$ & 0.07 & 0.0395 & 0.1090 & 0.07 & 0.14 & 0.05 \\
\hline
\end{tabular}

Note: $\mathrm{a}=$ regression coefficient for association between perceived $\mathrm{T} \& \mathrm{D}$ and mediator; $\mathrm{b}=$ regression coefficient for association between mediator and intention to stay(DV) when predictors are also included; c' regression coefficient for association between perceived T\&D and intention to stay (DV) when predictors and mediators are also included - direct effect; $a^{*} b=$ regression coefficient for indirect association between perceived T\&D and intention to stay, via mediator - indirect effect; and $c=$ sum of $\mathrm{a}^{*} \mathrm{~b}$ and c' - total effect. 
Table 7. Effects of each work attitude individually on intention to stay

\begin{tabular}{|c|c|c|c|c|c|c|c|c|c|c|c|c|}
\hline & \multicolumn{3}{|c|}{ Job Satisfaction Only } & \multicolumn{3}{|c|}{ Emotional Exhaustion Only } & \multicolumn{3}{|c|}{$\begin{array}{c}\text { Change-Related Anxiety } \\
\text { Only }\end{array}$} & \multicolumn{3}{|c|}{$\begin{array}{c}\text { Employee Engagement } \\
\text { Only }\end{array}$} \\
\hline & Est. & SE & $\mathrm{t}$ & Est. & SE & $\mathrm{t}$ & Est. & SE & $\mathrm{t}$ & Est. & SE & $\mathrm{t}$ \\
\hline Intercept & 2.45 & 0.21 & $11.56 * * *$ & 2.36 & 0.21 & $11.43 * * *$ & 2.34 & 0.21 & $10.91 * * *$ & 2.31 & 0.21 & $10.99^{* * *}$ \\
\hline Gender & 0.14 & 0.06 & $2.37^{*}$ & 0.13 & 0.06 & $2.22 *$ & 0.13 & 0.06 & $2.14^{*}$ & 0.15 & 0.06 & $2.49^{*}$ \\
\hline Age & 0.15 & 0.03 & $4.99 * * *$ & 0.17 & 0.03 & $5.52 * * *$ & 0.17 & 0.03 & $5.50 * * *$ & 0.15 & 0.03 & $5.19 * * *$ \\
\hline Tenure & 0.07 & 0.03 & $2.34^{*}$ & 0.08 & 0.03 & $2.54 * *$ & 0.08 & 0.03 & $2.47^{*}$ & 0.10 & 0.03 & $3.19 * * *$ \\
\hline $\begin{array}{l}\text { Management } \\
\text { Responsibility }\end{array}$ & -0.02 & 0.08 & 0.29 & 0.04 & 0.08 & 0.49 & 0.03 & 0.08 & 0.35 & -0.06 & 0.08 & 0.80 \\
\hline $\begin{array}{l}\text { Perceived } \\
\text { T\&D }\end{array}$ & 0.12 & 0.03 & $3.63 * * *$ & 0.23 & 0.03 & $6.98 * * *$ & 0.24 & 0.03 & $7.41 * * *$ & 0.14 & 0.04 & $4.00 * * *$ \\
\hline $\begin{array}{l}\text { Job } \\
\text { Satisfaction }\end{array}$ & 0.35 & 0.03 & $11.22 * * *$ & & & & & & & & & \\
\hline $\begin{array}{l}\text { Emotional } \\
\text { Exhaustion }\end{array}$ & & & & -0.14 & 0.03 & $4.39 * * *$ & & & & & & \\
\hline $\begin{array}{l}\text { Change- } \\
\text { Related } \\
\text { Anxiety }\end{array}$ & & & & & & & -0.11 & 0.03 & $3.74 * * *$ & & & \\
\hline $\begin{array}{l}\text { Employee } \\
\text { Engagement }\end{array}$ & & & & & & & & & & 0.46 & 0.06 & $8.05 * * *$ \\
\hline $\begin{array}{l}-2 * \log \\
\text { likelihood }\end{array}$ & 3068.24 & & & 3168.83 & & & 3173.9 & & & 3124.7 & & \\
\hline $\begin{array}{l}\text { Variance } \\
\text { between-orgs }\end{array}$ & .18 & & & .16 & & & .18 & & & .17 & & \\
\hline $\begin{array}{l}\text { Variance } \\
\text { within-orgs }\end{array}$ & .76 & & & .83 & & & .83 & & & .80 & & \\
\hline
\end{tabular}


Outcomes

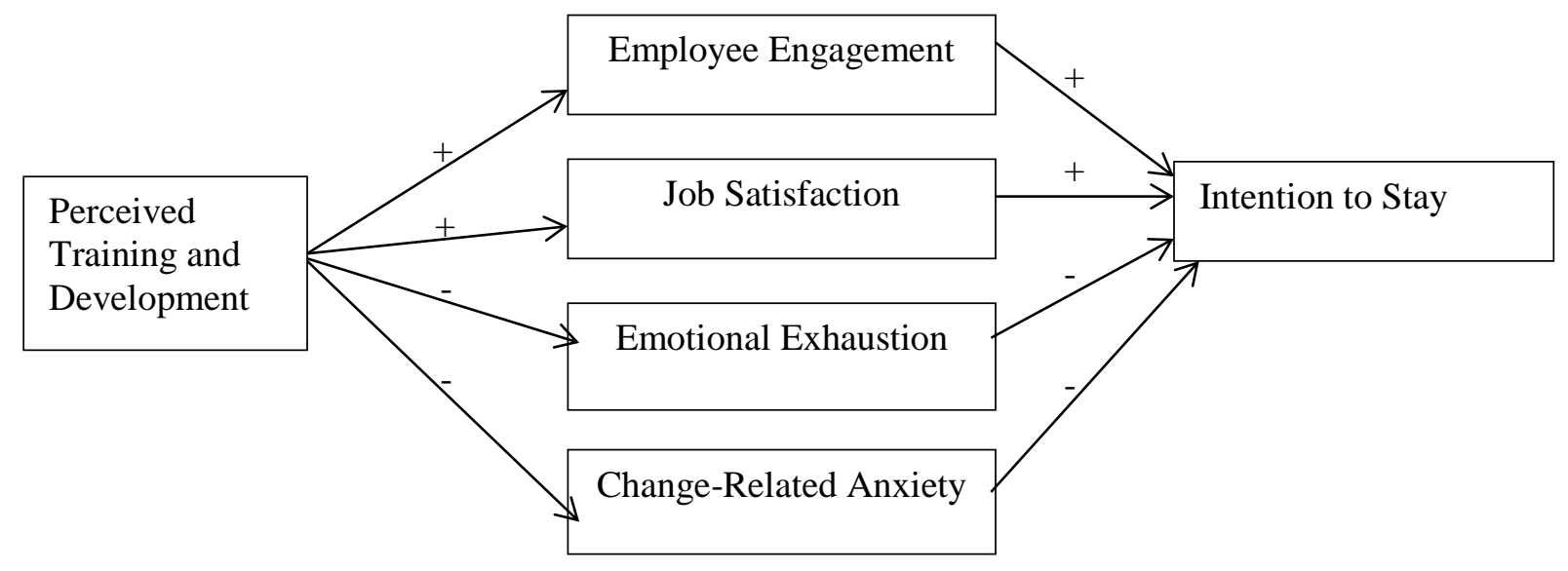

Figure 1. Illustration of the hypothesized model being tested 


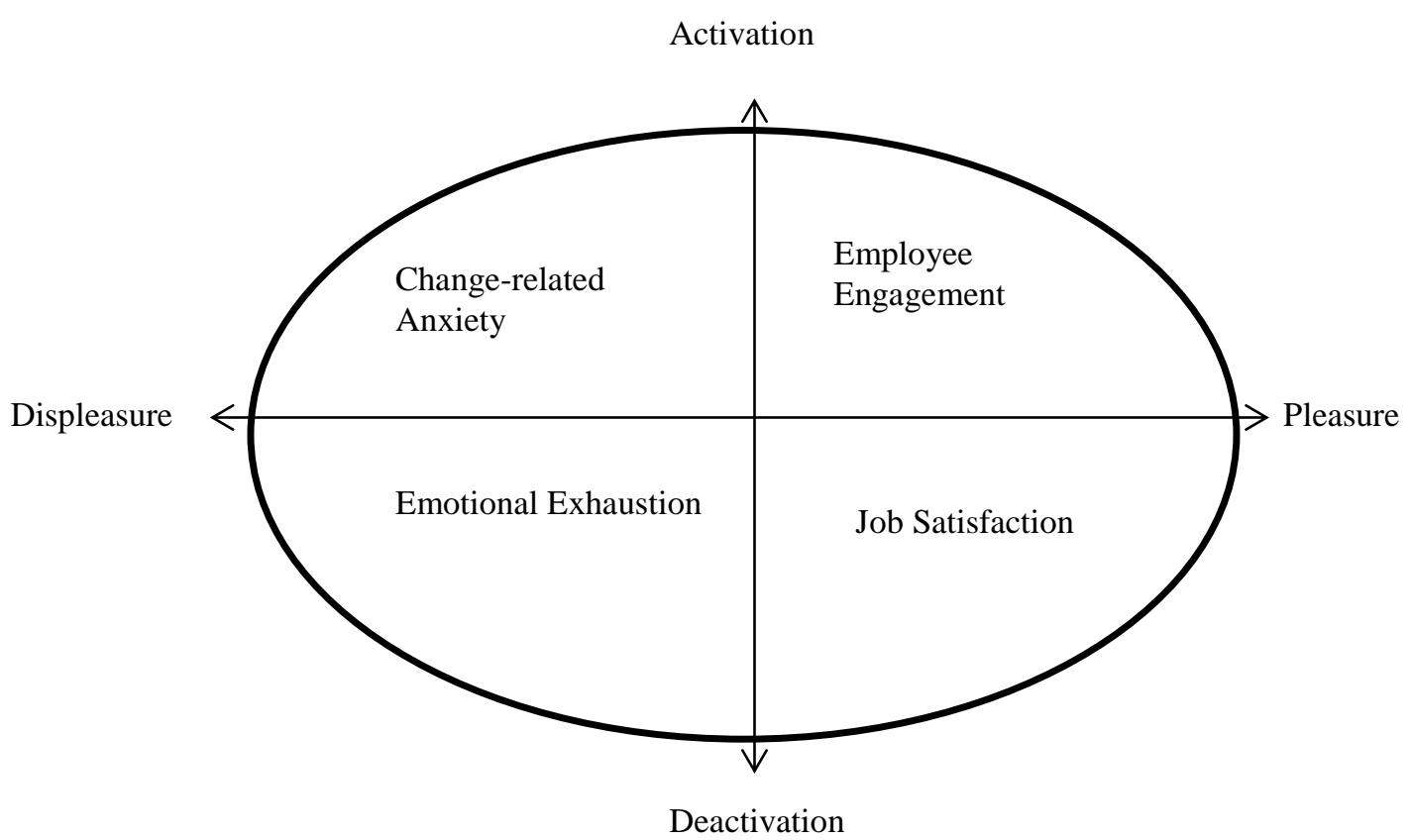

Figure 2. Theoretical model of work attitudes adapted from Russell's (1980) model of core affect 